\title{
Analisis Perubahan Orientasi Pola Hidup Mahasiswa Pasca Berakhirnya Masa Pandemi Covid-19
}

\author{
Bilqis Farah $^{1}$, Robby Darwis Nasution ${ }^{2}$ \\ ${ }^{1,2}$ Program Studi Ilmu Pemerintahan, Universitas Muhammadiyah Ponorogo, Indonesia \\ Korespondensi*: bilqisfarah3@gmail.com
}

\begin{abstract}
ABSTRAK
Tujuan dari penelitian ini adalah berupa bentuk analisis terhadap kemungkinan perubahan orientasi pada kehidupan mahasiswa pasca berakhirnya masa pandemi Covid-19. Metode yang dilakukan adalah dengan (studi kepustakaan) dimana mengamati fenomena yang terjadi serta didukung berbagai penelitian, artikel, maupun opini terkait untuk kemudian dijelaskan secara deskriptif. Kesimpulan dari penelitian ini adalah mahasiswa sangat berpotensi besar untuk mengalami perubahan pada pola hidup dan interaksi akibat penerapan belajar online. Eksistensi mahasiswa menjadi dikhawatirkan, sehingga hal ini mengancam terbentuknya generasi intelektual yang berkualitas. Mengingat saat ini pola interaksi dan pembelajaran pada mahasiswa menjadi berbeda, serta mereka juga berada dalam tahap penyesuaian. Hal ini dapat disimpulkan sebagai suatu permasalahan kompleks, tentang realitas sosial yang telah terjadi dan diprediksi pada kalangan mahasiswa. Maka dari itu, pola pembelajaran online merupakan sesuatu yang tak boleh habis untuk dikaji.
\end{abstract}

Kata Kunci: Perubahan Orientasi, Pola Hidup Mahasiswa, Covid - 19

\begin{abstract}
The purpose of this study is in the form of an analysis of possible changes in orientation in student life after the end of the Covid-19 pandemic. The method used is (literature study) which observes phenomena that occur and is supported by a variety of research, articles, and related opinions to then be explained descriptively. The conclusion of this study is that students have great potential to experience changes in lifestyle and interaction due to the application of online learning. The existence of students becomes a concern, so this threatens the formation of a generation of qualified intellectuals. Given the current patterns of interaction and learning in students to be different, and they are also in the adjustment phase. This can be concluded as a complex problem, about the social reality that has occurred and predicted among students. Therefore, online learning patterns are something that must not be exhausted to be studied.
\end{abstract}

Keywords: Change in Orientation, Student Life Patterns, Covid - 19 


\section{PENDAHULUAN}

Kini masyarakat dunia telah dibuat resah karena wabah Covid-19 yang pada akhirnya menjadi sebuah wabah pandemi, karena sudah berlangsung sejak beberapa bulan lalu. Dampaknya adalah seluruh negara dunia saat ini sedang berjibaku untuk menekan lonjakan angkat kematian, disamping itu juga belum ada vaksin handal yang mampu untuk menetralkan keberadaan virus ini.

Salah satu contoh tentang upaya yang dilakukan oleh pemerintah di berbagai belahan dunia adalah dengan menerapkan jenis kebijakan seperti melakukan lockdown, karantina wilayah, dan pembatasan kontak fisik terutama bagi daerah yang sudah dikategorikan masuk ke dalan zona merah (Nurkholis, 2019).

Seluruh dunia tengah mengalami krisis multidimensi akibat serangan virus tersebut. Dari mulai jatuhnya korban jiwa, serta krisis yang paling vital sekali pun seperti ekonomi, bisnis, turunnya devisa negara, pemutusan hubungan kerja secara massal, dan lain sebagainya. Secara garis besar dapat dikatakan bahwa virus ini telah melemahkan aktivitas manusia secara keseluruhan, sehingga muncul gejala-gejala krisis yang pada akhirnya menuntut manusia untuk mencari margin sekecil apapun dalam rangka survive (bertahan hidup).
Di sisi lain, pihak pemerintah yang merupakan otoritas paling tinggi dalam suatu negara juga tengah berlomba-lomba untuk menemukan formula terbaik dalam usaha mempertahankan kelangsungan hidup warga negara nya. Tak terkecuali di Indonesia, pemerintah dan masyarakat nya pun juga memiliki porsi beban tanggungan yang sama dalam melewati masa-masa krisis akibat Covid-19 ini.

Penyebaran Covid-19 sangat cepat terjadi, adapun berdasarkan pada data temuan World Health Organization (WHO) menyebutkan bahwa sampai saat ini telah tercatat kurang lebih 287.525 korban meninggal dunia dari total 215 negara yang ada di dunia, dan sisanya menyebutkan angka 4.179.479 juta jiwa dalam kondisi positif terkena serangan. Sedangkan di Indonesia sendiri, sampai saat initelah tercatat 1.028 korban meninggal dunia, lalu 15.438 mengidap gejala positif, dan 3.287 telah mengalai fase kesembuhan (Covid19.co.id, 2020).

Pemerintah Indonesia sudah melakukan berbagai upaya pencegahan, sebagai langkah antisipatif untuk memputus mata rantai penyebaran Covid-19 mulai dari mewajibkan masyarakat untuk menjaga imunitas tubuh, menjaga kebersihan, memakai masker, menghindari kerumunan, memperbanyak minum air putih, serta berbagai anjuran lainnya sesuai dengan 
protokol kesehatan yang berlaku. Selain itu, pemerintah juga mengajurkan untuk sebisa mungkin agar tidak keluar rumah.

Sebagaimana yang diketahui, bahwa virus Covid-19 ini telah menjadi perbincangan global sejak akhir Desember 2019 yang diyakini bersumber di kota Wuhan, Provinsi Hubei, China. Sifat penyebarannya adalah sangat cepat dari manusia satu ke manusia lain, dan gejala nya adalah menyerang organ saluran pernafasan manusia. Secara tegas pemerintah telah menetapkan status virus ini sebagai bencana nasional non alam, bila mana mengacu pada Pasal 7 ayat 2 UU No.24 Tahun 2007 Tentang Penanggulangan Bencana (Setyawati, 2020).

Berbagai permasalahan yang terjadi akibat Covid-19, saat ini memang telah menjadi menunjukan gejala yang serius, mengingat efek yang ditimbulkan telah merubah banyak pola kehidupan dalam berbagai bidang seperti: ekonomi, perdagangan, pariwisata, pendidikan, komunikasi, interaksi, dsb. Salah satu yang patut disoroti adalah dalam bidang pendidikan, dimana telah nampak terjadi perubahan secara mendasar.

Faktanya permasalahan tersebut telah mengubah lahirnya kebijakan tentang perubahan gaya belajar dari metode lama yang biasanya dilakukan sehari-hari, saat ini para siswa dan mahasiswa diwajibkan untuk melakukan kegiatan belajar dari rumah dengan memanfaatkan berbagai macam aplikasi maupun platform berbasis online, sehingga intensitas untuk bertemu dan bertatap muka menjadi nihil.

Melalui surat Edaran oleh Kementrian Pendidikan dan Kebudayaan Direktorat Pendidikan Tinggi No.1 Tahun 2020 tentang pencegahan penyebaran Corona Virus Disease (Covid-19) di perguruan tinggi, telah direalisasikan kebijakan baru yang menuntut dan menyarankan kepada seluruh perguruan tinggi di Indonesia untuk memulai pembelajaran jarak jauh, atau dalam arti lain adalah para mahasiswa diharuskan untuk melakukan perkuliahan di rumah masing-masing.

Akhirnya setelah instruksi tersebut muncul, berbagai perguruan tinggi dengan sigap menyambut secara positif. Selain itu, Organisasi Kesehatan Dunia WHO juga memberikan rekomendasi keras agar melakukan penghentian sementara terhadap segala bentuk aktivitas maupun kegiatan yang berpotensi menjalin kontak fisik ataupun mengumpulkan massa dalam jumlah banyak (Firman \& Rahayu, 2020).

Husamah (2015) mengatakan bahwa perkuliahan secara online memiliki keuntungan maupun beberapa dampak positif seperti: 1) membentuk sifat disiplin secara mental dan formal, 2) memberikan kemudahan bagi penguatan, 3) proses 
penilaian oleh dosen menjadi lebih optimal,

4) interaksi antar mahasiswa atau perserta didik dapat secara langsung diamati oleh dosen terutama dalam proses menerima/mendengarkan materi.

Namun selain adanya sisi kelebihan, Husamah (2015) juga memberikan garis besar kelemahan dari adanya belajar online seperti : 1) proses pembelajaran menjadi kaku, 2) pembelajaran online yang monoton dan klasik akan cenderung tidak dapat mengakomodasi gaya belajar masingmasing peserta didik/mahasiswa yang tentunya bervariasi, 3) pembejalaran yang hanya berlaku satu arah (monoton) menciptakan peluang untuk menurunnya daya kreativitas serta inovasi (Khasanah et al., 2020).

Kasus yang dapat dijadikan contoh diantaranya adalah berbagai keluhan yang datang dari mahasiswa dan siswa, yang merasa bahwa kebijakan untuk belajar di rumah justru menambah beban bagi mereka. Keluhan tersebut didasari dengan sulitnya sinyal internet, kuota internet, serta berbagai macam penugasan yang justru melelahkan secara fisik dan psikologis (Pratiwi, 2020). Keluhan mahasiswa lain juga muncul dengan alasan sulitnya memahami materi pelajaran melalui kuliah online seperti materi speaking dalam mata kuliah bahasa inggris, dikarenakan ketidakstabilan server dan sinyal internet sehingga optimalisasi perkuliahan tidak di dapat (Masriadi \& Ika, 2020).

Dampak lanjutan yang dapat dirasakan adalah tentang interaksi antara siswa dan guru juga berkurang, begitu juga antar mahasiswa dan dosen yang biasanya memang cenderung dipenuhi diskusi serta tanya jawab dalam setiap pertemuan. Pola pikir, kehidupan, dan perilaku dalam hal akademik juga menjadi tak menentu karena banyaknya intensitas waktu serta perubahan metode yang ada.

Terkhusus untuk para mahasiswa yang sudah familiar dengan label para pemikir, sekarang ini menjadi seolah tak berdaya akibat terhimpit dengan metode dan gaya belajar baru. Singkatnya adalah, telah terjadi penundaan dalam penggalian potensi keilmuan dan penelitian yang biasanya memang menjadi makanan sehari-hari bagi mahasiswa.

Terkait orientasi pola hidup, jika merujuk pada definisi dari Erikson (1989) memberikan anggapan masa pencarian identitas diri biasanya dilakukan ketika remaja. Identitas diri adalah kesadaran yang timbul dari seseorang terkait dengan kepribadian, tujuan hidup, kepuasan hidup, serta dapat mengatur orientasi hidupnya setiap saat. Dalam hal ini mahasiswa termasuk dalam kategori seseorang yang berorientasi kepada segala aspek kehidupan 
karena berada dalam masa remaja menuju dewasa.

Menurut Ames (1992) perkembangan usia pada mahasiswa telah secara jelas melahirkan pemikiran maupun tujuan pencapaian yang hendak di raih ke depan, seperti tujuan perilaku dan prestasi. Hal ini menjabarkan secara rinci terkait pola keyakinan serta niat untuk berpengaruh dan melibatkan diri dalam kegiatan yang mengandung prestasi (Sari, 2014).

Pola hidup atau pun gaya hidup merupakan hal yang tidak bisa dilepaskan dari keseharian mahasiswa, dimana selalu terjadi dinamika dari wakt ke waktu. Sifat dari gaya hidup dapat dilihat dari indikator yang diperlihatkan sehari-hari ketika seseorang berinteraksi dengan lingkungan, karena selalu muncul motivasi agar citra seseorang tetap baik dalam pandangan masyarakat/lingkungan. Alasan lain adalah, dikarenakan sebuah image adalah bentuk konkrit yang melekat dan dapat secara jelas dilihat oleh pengamatan orang lain melalui pola dan tingkah laku yang dilakukan.

Pola hidup pada kalangan mahasiswa biasanya berkaitan erat dengan perkembangan dan budaya luar, baik yang bersifat positif atau negatif. Bisa dikatakan bahwa budaya luar telah menjadi referensi bagi seseorang/mahasiswa untuk tetap tampil eksis sesuai kehendak. Gaya hidup mahasiswa saat ini cenderung beroritentasi kepada hedonis, atau dengan kata lain adalah serangkain pola hidup yang bertujuan untuk mencari kesenangan semata, membeli barang mahal, atau pun penuh dengan hasrat ingin diperhatikan (Vacliuca \& Yasir, 2016).

Bagaimanapun pola dan gaya hidup mahasiswa di masa pandemi ini menjadi lebih berubah dari biasanya, dimana lebih banyak waktu luang, borosnya kuota (konsumtif), tidak optimalnya belajar online, kurangnya interaksi dengan lingkungan luar, dan lain sebagainya. Pembelajaran online yang tengah berlaku ini memang harus dimaknai secara luas dan kritis, supaya seluruh pihak (terutama pemerintah) dapat melakukan pemetaan terhadap kondisi di lapangan. Sehingga berdasarkan pemetaan tersebut maka akan muncul bahan analisis yang kemudian dapat dipergunakan untuk sarana evaluasi lebih lanjut, mengingat berakhirnya masa pandemi Covid-19 ini belum dapat diprediksi secara pasti baik dari segi dampak jangka panjang serta jangka pendek.

Berdasarkan penjelasan dan latarbelakang diatas, maka dalam penelitian ini akan dikaji tentang analisis mengenai perubahan orientasi pola kehidupan mahasiswa pasca pandemi Covid-19 berakhir. Pertanyaan turunan dari fokus penelitian daiatas adalah pertama, bagaimana perubahan orientasi pola kehidupan yang akan terjadi pada kalangan 
mahasiswa pasca masa pandemi Covid-19 berakhir? Kedua, Apa saja pergeseran dan perubahan pola perilaku yang mungkin terjadi?

\section{METODE PENELITIAN}

Penelitian ini menaruh titik fokus fenomena saat ini yang terjadi yakni tentang bagaimana analisis terhadap orientasi pada mahasiswa ketika masa pandemi berakhir. Orientasi yang dimaksud disini adalah tentang keseluruhan pola hidup yang mencakup perilaku, interaksi, gaya hidup, komunikasi, kecenderungan sosial, diskusi, dan lain sebagainya.

Penelitian ini dilakukan dengan studi kepustakaan (library riset) yakni mengamati berbagai data dari pemberitaan-pemberitaan terbaru, serta mempelajari objek-objek yang terkait secara langsung di dalamnya dengan data dan literature ilmiah dari berbagai sumber. Adapun menurut Nawawi dalam (Lopa, 2019) menyatakan bahwa data studi kasus data diperoleh dari semua pihak yang saling terkait, atau dengan kata lain adalah dikumpulkan dari berbagai sumber.

\section{HASIL DAN PEMBAHASAN}

\section{Orientasi Mahasiswa di Masa Pandemi}

\section{Covid-19}

Sebelumnya, perlu diketahui dulu tentang definisi atau pun pengertian dari istilah mahasiswa sebagai pengantar dalam penelitian ini. Menurut Knopfemacher dalam (Kurniawati \& Baroroh, 2016) dikatakan bahwa "mahasiswa merupakan golongan orang-orang yang memiliki kedekatan dengan kehidupan dan elemen masyarakat dan semakin menyatu, serta tengah berada dalam masa didikan dan diharapkan menjadi calon intelektual di masa depan".

Definisi tersebut di atas sebenarnya menandakan bahwa status yang melekat pada mahasiswa selama ini, sudah sejak lama dianggap sebagai kelompok maupun golongan yang sarat akan keilmuan. Maka dari itu, tak heran jika mahasiswa merupakan salah satu agen perubahan yang selama ini juga digadang-gadang oleh masyarakkat luas. Karena secara sifat, mahasiswa tentunya memiliki wawasan dan pergaulan yang lebih luas dengan berbagai macam jaringan-jaringan penting seperti pemerintah (pemangku kebijakan).

Faktanya, hampir setiap hari mahasiswa dapat dikatakan bersinggungan dengan kehidupan masyarakat luas baik di kota besar dan kecil sekali pun. Kemudian, tak jarang juga kegiatan kalangan mahasiswa yang menitikberatkan kepada kepentingan serta kebutuhan masyarakat.

Mulai dari berbagai kegiatan, sosialisasi, pengabdian, relawan, edukasi, dan lain sebagainya. Namun di masa pandemi Covid19 ini, kita dapat mengamati bahwa seluruh pola kegiatan dan aktivitas mahasiswa yang 
biasanya dilakukan pada akhirnya mengalami vakum.

Dikarenakan situasi dan kondisi yang tidak memungkinkan, serta besarnya rasa cemas yang hinggap di masyarakat akibat ancaman Covid-19. Sehingga masyarakat pun menjadi antipasti dengan kehadiran orang asing, begitu pun dengan kalangan mahasiswa sendiri yang tentu tidak diketahui sejauh mana mereka menjaga pola dan bentuk kegiatannya dengan cara lain. Gejala ini sangat merefleksikan sebuah tarik menarik yang terjadi antara pengaruh baru dan gaya lama, dimana selalu ada kemungkinkan untuk adanya pergeseran.

Mahasiswa dapat menentukan langkah maupun arah geraknya sendiri, karena memang tidak ada aturan baku yang menuntut secara wajib. Andaikata ada istilah bahwa mahasiswa dianggep sebagai salah satu elemen pendorong dan perubahan, maka hal tersebut bisa dibilang hanya lah status moralitas yang melekat. Karena tidak semua mahasiswa memiliki kecenderungan dan motivasi terhadap status tersebut, dikarenakan perbedaan tipe maupun karakteristik masing-masing individu yang tentunya didasari oleh banyak pengaruh seperti: keluarga, teman, lingkungan, jaringan, organisasi, sahabat, dsb.

Salah satu contoh yang dapat diambil adalah dalam penelitian (Rani et al., 2019) yang memberikan fakta dan salah satu kebiasaan pada kehidupan mahasiswa modern yakni dengan cara bermain game online secara berkelompok. Kemudian disebutkan beberapa kerugian akibat menjadikan bermain game online sebagai bagian dari kehidupan, seperti: buang-buang waktu, lupa waktu, boros keuangan, acuh dengan lingkungan dan orang sekitar, serta mudah berkata kasar maupun mengeluarkan cari maki kepada lawan.

Peneliti menjadikan kasus ini sebagai contoh dalam menggambarkan perilaku kalangan mahasiswa secara umum, yakni diluar pelaksanaan perkuliahan akibat Covid-19. Singkatnya adalah mahasiswa memiliki potensi dan kebebasan nonakademik, dikarenakan tidak ada pihak yang memberikan kontrol.

\section{Efektivitas Pembelajaran Online Saat ini}

Pembelajaran Online ataupun istilah virtual learning merupakan suatu terobosan modern yang memungkinkan setiap orang untuk melakukan pembelajaran tanpa proses tatap muka di dalam ruang-ruang kelas. Konsep pembelajaran online ini sebenarnya ditengarai agar berujung pada peningkatan efektivitas serta efisiensi, dengan dukungan kemajuan teknologi informasi.

Kemajuan teknologi informasi mulai mencuat untuk menunjang kebutuhan orang, yang dibuktikan dengan adanya fakta tentang pembelajaran online. Namun yang 
dikhawatirkan dari adanya kecenderungan terhadap penggunaan teknologi sebagai penunjang pembelajaran online adalah minimnya interaksi yang terjalin di masa depan, apabila pola pembelajaran online terus menerus dilakukan sebagai konsep tunggal dalam suatu negara (Nasution, 2015).

Di masa Pandemi Covid-19 ini, sejatinya konsep pembelajaran online adalah alternative yang tidak dapat ditolak lagi keberadaanya. Logisnya adalah karena keadaan dan situasi krisis di tengah ancaman, sehingga memaksa terjadinya pergeseran pola. Dari yang biasanya mengacu pada pembelajaran di dalam kelas, secara drastis telah berubah kepada pembelajaran online melalui pemanfaatan teknologi.

Seiring dengan diterapkanya sistem belajar online di Indonesia di tengah ancaman Covid-19 ini, sebenarnya bisa dibilang adalah satu fenomena yang menjadi solusi atas kesenjangan ruang dan waktu antara mahasiswa, siswa, maupun tenaga pengajar. Menurut (Nasution, 2015), setidaknya ada beberapa hal yang perlu dijadikan prioritas utama dalam menunjang sistem pembelajaran online atau (virtual learning) yakni adalah sebagai berikut : (1) Ketersediaan hardware dan software pendukung yang modern, (2) Infrastruktur jaringan internet yang memadai, (3)
Kebijakan yang mendukung penerapan virual class. Selain itu, baik siswa ataupun mahasiswa sebenarnya juga dituntut untuk memiliki kemampuan dasar dalam penggunaan teknologi seperti etika online, keterampilan sosial online, mekanisme penelusuran literature web, dan lain sebagainya (Nasution, 2015).

Dapat dikatakan bahwa 3 aspek di atas adalah aspek keterjaminan yang memang harus diupayakan dengan maksimal oleh pemerintah Indonesia maupun pihak pemangku kebijakan. Terpangkasnya jarak, waktu, dan perubahan gaya belajar yang terjadi saat masa pandemi ini adalah suatu hal yang lumrah. Dalam hal ini, mahasiswa menjadi cenderung dipaksa dan terpaksa untuk menyesuaikan diri dan menghilangkan habitat lama. Selain itu, penerapan pembelajaran online di masa ini juga merupakan ajang yang tepat bagi pemerintah Indonesia untuk terus mengembangkan dan mengevaluasi tentang sejauh mana efektivitas yang telah dicapai dari hasil penerapan yang telah dilakukan.

\section{Dampak Covid-19 Terhadap Pola Pembelajaran Mahasiswa}

Pola kegiatan dan pembelajaran mahasiswa saat ini seluruhnya beralih dengan menggunakan metode online, atau istilah lainnya adalah e-learning. Lebih spesifiknya adalah, bagi seluruh sekolah 
maupun perguruan tinggi diwajibkan untuk tidak melakukan pola belajar lama (tatap muka), serta menggantinya dengan pembelajaran jarak jauh melalui perantara platform/aplikasi pendukung.

Hal tersebut dibuktikan dengan keluarnya "Surat Edaran Nomor 3 Tahun 2020 Tentang Pencegahan Corona Virus Disease (COVID19)" oleh Kemdikbud sebagaimana dalam jurnal (Pratiwi, 2020). Lebih lanjut, penelitian dalam jurnal (Pratiwi, 2020) juga menyebutkan tentang penggunaan berbagai macam aplikasi (Schoology, Google Clasroom, Zoom) oleh Dosen dan Mahasiswa di Universitas Kristen Satya Wacana.

Adapun mengenai konsep yang dilakukan oleh Dosen adalah tatap muka secara online, berdiskusi dengan fleksibel dan memaksimalkan kelas virtual, serta pembagian materi berbentuk file. Meskipun tidak dapat dipungkiri ada kendala yang dialami, yakni paling kentara adalah soal tidak stabil dan lambatnya koneksi internet yang tentunya berbeda-beda pada tiap mahasiswa. Selain itu, dikatakan juga bahwa aplikasi seperti Zoom memang sangat boros dalam menghabiskan kuota.

Walaupun di sisi lain, mahasiswa yang menjadi informan mengaku bahwa pembelajaran berjalan dengan efektif karena dosen yang mengajar selalu berupaya untuk memperhatikan keluhan dan tanggapan mahasiswa, sehingga apabila ada sesuatu yang kurang jelas dan tidak terdengar atau delay maka dosen akan mengulang pembicaraan. Jadi secara garis besar, interaksi yang terjalin dan proses diskusi maupun pembelajaran antara dosen dan mahasiswa memang hanya dilakukan secara maya.

Sebenarnya jika ditelaah lebih lanjut terkait dengan konsep dan metode pembelajaran yang telah diterapkan secara online oleh Universitas Kristen Satya Wacana di tengah wabah Covid-19 ini, faktanya sejalan dengan teori dari Basori (2017), dalam (Pratiwi, 2020). Dikatakan bahwa "model pembelajaran yang memanfaatkan fungsi dan peran dari teknologi adalah membantu dosen dan mahasiswa dalam proses pengelolaan pembelajaran".

Selain itu Sriwihajriyah dalam (Pratiwi, 2020) juga mengatakan bahwa peranan dari teknologi dapat memberikan, mendorong, dan menyokong terciptanya peningkatkan nilai maupun sisi efisiensi yang lebih baik bagi mahasiswa dan dosen sebagai sumber belajar dan sarana evaluatif.

Pembelajaran online memberikan peluang kepada para mahasiswa yang aktif untuk menunjang dan meningkatkan kebutuhan prestasi akademinya. Dalam konteks pembelajaran, pemanfaat internet juga membantu untuk meningkatkan sisi 
kemandirian kepada para mahasiswa agar tujuannya dapat tercapai. Alasan yang mendasari adalah, mahasiswa dapat melakukan bebas akses seluas-luasnya untuk memperoleh bahan pembelajaran secara online seperti dari perpustakaan, peristiwa sejarah, rekaman wawancara, laporan ilmiah, dan data statistik (Pujilestari, 2020).

Maka dari itu, konsep dan metode online yang melibatkan kehadiran teknologi ini memang sangat relevan jika diterapkan saat ini sebagai solusi dan upaya untuk memutus mata rantai penyebaran Covid-19 dengan catatan tetap dibarengi langkah evaluasi dan pengembangan berjenjang. Termasuk di dalamnya juga tetap memperhatikan kaidah yang berlaku, serta memberikan kelonggaran bagi para mahasiswa yang memiliki kendala dalam permasalahan leletnya jaringan internet (karena perbedaan provider dan wilayah). Dosen harus memiliki pola pemikiran yang lebih visioner, dengan mempertimbangkan segala aspek ke depannya.

Melihat pandangan yang lebih jauh, seorang dosen yang memiliki kriteria tersebut tentunya akan lebih memberikan sumbangsih yang lebih berarti untuk mencetak kualitas SDM bagi para mahasiswa nya. Hal yang sangat dimungkinkan adalah, akan tetap terjaganya kualitas dan mutu perkuliahan di tengah berbagai macam hambatan skibat wabah
Covid-19 ini ketika dosen dan mahasiswa sama-sama menyadari tentang dinamika yang terjadi. Sehingga atas dasar kesadaran tersebut, tidak akan terjadi degradasi dalam hal pola pikir, pola hidup, maupun kebiasaan-kebiasaan mahasiswa.

\section{Perubahan Orientasi Pola Hidup Mahasiswa}

Salah satu artikel yang memberikan alasan secara kritis adalah dapat ditemukan pada penelitian (Kurniawati \& Baroroh, 2016), yang pada intinya adalah memberikan narasi secara lugas kepada publik, termasuk kepada kalangan mahasiswa sendiri tentang sejauh mana peranan dan status mereka di masa pandemi ini. Salah satu kutipan yang menarik adalah, artikel tersebut begitu sangat menyayangkan jika waktu luang yang dimiliki oleh kalangan mahasiswa saat ini hanya dihabiskan atau pun berkutat pada pengerjaan tugas-tugas semata. Padahal di luar sana, mahasiswa diharapkan memiliki kepekaan sebagai pengontrol kehidupan sosial.

Faktanya terdapat beberapa potensi yang bisa dilakukan oleh mahasiswa, untuk tetap eksis dan mengisi hari-hari dengan sesuatu yang kreatif. Seperti menjadi relawan Covid-19, menggalang donasi, bagi-bagi masker, membantu pengiriman logistik, dan segala sesuatu yang bertujuan untuk 
meringankan beban para petugas dalam perjuangan menyudahi penyebaran Covid19.

Selain itu, sebenarnya mahasiswa yang selama ini dibekali dan diasah sisi intelektualnya tentu dapat melakukan berbagai macam terobosan melalui media sosial dalam rangka melawan Covid-19. Hal ini bisa dilakukan dengan cara memberikan edukasi tentang protokol kesehatan kepada masyarakat dengan berupa gambar, tulisan, maupun video.

Jika dianalisa secara mendalam, rasanya memang sangat tepat sekali apabila membenturkan kehidupan dan status mahasiswa dengan fenomena krisis akibat Covid-19 saat ini. Disini dapat dikatakan secara tegas, bahwa kehadiran mahasiswa masih sangat diharapkan oleh masyarakat luas melalui gerakan-gerakan sosialnya. Secara usia, mahasiswa sangat tergolong muda dan tentunya penuh dengan energi dan kekayaan ide untuk kemudian bergerak.

Ditambah lagi dengan jaringan kemahasiswaan yang tersebar luas di Indonesia, maka aspek ini benar-benar sangat memberikan support yang berarti. Selain itu juga kita tidak boleh lupa tentang perkembangan informasi dan kemajuan tekhnologi di masa kini, dimana setiap hari nya seluruh orang bersentuhan dengan aspek tersebut (termasuk kalangan mahasiswa itu sendiri).
Mahasiswa dapat disebut telah memiliki gerbong dan koridornya sendiri, dalam berpijak untuk menata pola hidup di lingkungan masyarakat. Luasnya keilmuan juga turut menambah nilai jual maupun eksistensi mahasiswa di mata masyarakat. Eksistensi yang dimaksud adalah bagian dari pola dan cara untuk melalui hari-hari, di tengah dinamika kehidupan saat ini terutama akibat Covid-19 yang tak kunjung mereda.

Sikap pasif (kaku dan acuh) terhadap suatu peristiwa dalam kehidupan (realitas sosial) adalah pilihan yang tidak tepat bagi kalangan mahasiswa, namun sikap aktif lah yang merupakan pilihan mutlak yang tentunya bakal menuai apresiasi besar. Jalan pikiran mahasiswa pada akhirnya dapat menjadi indikator penentu untuk memulai bergerak atau sekedar diam tanpa resiko.

Banyak prediksi dan kemungkinan yang bisa ditafsirkan pada kehidupan di masa depan yang bisa berdampak pada kehidupan pada kalangan mahasiswa. Beberapa contoh perubahan pola hidup, interaksi, dan gaya hidup di masa depan (berakhirnya Covid-19) adalah:

1) Mahasiswa menjadi canggung dan kaku ketika bersentuhan dengan lingkungan sosial, seperti teman, masyarakat, dosen, relasi, dsb.

2) Perilaku konsumtif dan ketergantungan yang tinggi terhadap tekhnologi, 
sehingga kualitas dan pengembangan diri menjadi menurun.

\section{SIMPULAN}

Dampak yang disebabkan oleh adanya wabah Global pandemi Covid-19 telah secara nyata memberikan perubahan pola pada sistem pembelajaran antara dosen dan mahasiswa di Indonesia. Seakan telah memasuki era baru, adanya sistem pembelajaran online memang menjadi solusi tunggal untuk tetap memeprtahankan eksistensi pendidikan di tengah datangnya permasalahan.

Pemanfaatan teknologi sebagai sarana penunjang untuk kebutuhan belajar online (virtual) maka telah menciptakan sisi efektivitas dari segi efisiensi waktu, jarak, dan tempat. Di sisi lain, ada pula dampak yang kurang baik dari adanya pembelajaran online seperti kecenderungan mahasiswa yang malah konsumtif terhadap akses internet. Sehingga dikhawatirkan akan terbentuk semacam permasalahan baru, dimana model interaksi dan komunikasi antara mahasiswa menjadi kurang begitu intens.

Pola Kehidupan Mahasiswa yang biasanya berkutat dan sibuk di dalam kampus, pada akhirnya menjadi lebih fleksibel karena banyaknya waktu luang. Namun dalam sudut pandang yang lain, sebagian orang juga mengkhawatirkan hal ini dikarenakan mahasiswa menjadi acuh dengan kondisi sosial.

Sebagian orang memberikan gambaran, tentang Mahasiswa yang sebenarnya memiliki potensi untuk mengembangkan pola kegiatan diluar perkuliahan normal. Mahasiwa dapat memiliki kecenderungan untuk melakukan kegiatan sosial dan bersentuhan langsung dengan masyarakat, baik secara individu maupun kelompok.

Sistem Perkuliahan online rasanya belum dapat dibilang maksimal, karena beberapa kendala yang telah diakui. Sehingga hal ini menjadi bukti sekaligus memunculkan pertanyaan, yakni tentang sejauh mana mahasiswa mampu menyerap materi keilmuan selama masa pandemi Covid-19 ini. Parahnya lagi adalah tidak ada satu pun pihak yang sampai saat ini dapat memberikan prediksi konkrit dalam menentukan berakhirnya masa pandemi Covid-19. Secara otomatis, fakta tersebut juga memicu ketidakpastian dan kekhawatiran besar di benak publik terhadap masa depan.

Eksistensi mahasiswa menjadi dikhawatirkan, sehingga hal ini mengancam terbentuknya generasi intelektual yang berkualitas. Mengingat saat ini pola interaksi dan pembelajaran pada mahasiswa menjadi berbeda, serta mereka juga berada dalam tahap penyesuaian. Hal ini dapat disimpulkan sebagai suatu permasalahan 
kompleks, tentang realitas sosial yang telah terjadi dan diprediksi pada kalangan mahasiswa. Maka dari itu, pola pembelajaran online merupakan sesuatu yang tak boleh habis untuk dikaji.

Upaya untuk terus memperhatikan kalangan mahasiswa adalah harga mutlak. Walapun suatu perubahan nantinya tidak dapat terelakkan, namun sebuah upaya untuk meminimalisir juga harusnya terus digalakkan secara maksimal oleh pemerintah. Sehingga mahasiswa tidak terkesan terlempar dari lingkaran kehidupan

\section{UCAPAN TERIMA KASIH}

Penulis mengucapkan terima kasih kepada banyak pihak, terutama pengelola Jurnal Noken (Universitas Muhammadiyah pembimbing Bapak Robby Darwis Nasution, S.IP., M.A. yang menjadi penasihat terbaik dalam memulai maupun menyelesaikan penulisan. Serta kepada

\section{DAFTAR PUSTAKA}

Covid19.co.id. (2020). Data Sebaran Covid19. https://covid19.go.id/

Firman, \& Rahayu, S. (2020). Pembelajaran Online di Tengah Pandemi Covid-19. Indonesian Journal of Educational Science (IJES), 2(2), 81-89. https://doi.org/10.31605/ijes.v2i2.659

Khasanah, D. R. A. U., Pramudibyanto, H., \& Widuroyekti, B. (2020). Pendidikan Dalam Masa Pandemi Covid-19. Jurnal Sinestesia, 10(1), 41-48.

Kurniawati, J., \& Baroroh, S. (2016). Literasi Media Digital Mahasiswa sosial, atau pun terpinggirkan peran dan identitasnya sebagai sama-sama makhluk sosial di mata masyarakat.

Hakikat mahasiswa sebagai makhluk sosial memang tak boleh disepelekkan, namun juga tak boleh terlalu dianggap sebagai sesuatu yang lumrah oleh pemerintah. Jangan sampai hanya karena alasan Covid-19, pemerintah tidak boleh sampai antipati dan merasa cukup solutif dalam menata pola kehidupan mahasiswa saat ini dan hari-hari ke depan.

Sorong) yang telah memberikan acuan dan portal untuk mempublikasikan hasil tulisan peneliti. Kemudian juga kepada Dosen pemerintah, akademis, maupun para peneliti lain yang telah memberikan inspirasi melalui berbagai penelitian dan data-data seputar Covid-19.

Universitas Muhammadiyah Bengkulu. Jurnal Komunikator, 8(2), 51-66. http://journal.umy.ac.id/index.php/jkm /article/view/2069

Lopa, M. R. (2019). POLA PERILAKU MAHASISWA DAN PENGGUNAAN MEDIA SOSIAL. Jurnal Pendidikan Islam, 4.

Masriadi, \& Ika, A. (2020). Suka Duka Kuliah Online Saat Pandemi Corona Dosen Dan Mahasiswa Gaptek. https://regional.kompas.com/read/2020 /04/07/22044941/suka-duka-kuliahonline-saat-pandemi-corona-dosendan-mahasiswa-gaptek 
Nasution, R. D. (2015). MENEROPONG MASA DEPAN PENDIDIKAN DI INDONESIA (Penerapan Virtual Learning di Indonesia). PROSIDING SEMINAR NASIONAL PENDIDIKAN.

Nurkholis. (2019). Dampak Pandemi NovelCorona Virus Disease (Covid-19) Terhadap Psikologi dan Pendidikan Serta Kebijakan Pemerintah. Jurnal PGSD, 6.

Pratiwi, E. W. (2020). DAMPAK COVID19 TERHADAP KEGIATAN PEMBELAJARAN ONLINE DI SEBUAH PERGURUAN TINGGI KRISTEN DI INDONESIA. Perspektif Ilmu Pendidikan, 34(1).

Pujilestari, Y. (2020). Dampak Positif Pembelajaran Online Dalam Sistem Pendidikan Indonesia Pasca Pandemi Covid-19. Adalah: Buletin Hukum Dan Keadilan, 4(1), 49-56.

Rani, D., Hasibuan, E. J., \& Barus, R. K. I. (2019). Dampak Game Online Mobile Legends: Bang Bang terhadap Mahasiswa Impact of Online Mobile Legends Game: Bang Bang for Students. 7(1), 6-12.

Sari, R. (2014). ORIENTASI TUJUAN PADA MAHASISWA RIAU (PENDEKATAN INDIGENOUS PSYCHOLOGY). Universitas Islam Negeri Sarif Kasim Riau.

Setyawati, N. (2020). IMPLEMENTASI SANKSI PIDANA BAGI MASYARAKAT YANG BERAKTIVITAS DI LUAR RUMAH SAAT TERJADINYA PANDEMI COVID-19. Jurnal Education and Development, 8.

Vacliuca, Q., \& Yasir, Y. (2016). Representasi Gaya Hidup Mahasiswa Dalam Novel Good Memories Karya Lia Indra Andriana [Riau University]. In Jurnal Online Mahasiswa Fakultas
Ilmu Sosial dan Ilmu Politik Universitas Riau (Vol. 3, Issue 2). https://www.neliti.com/publications/19 0063/representasi-gaya-hidupmahasiswa-dalam-novel-goodmemories-karya-lia-indra-andr

\section{PROFIL SINGKAT}

Peneliti bernama Bilqis Farah, Lahir pada 19 Desember 1996 di kota Ponorogo . Saat ini sedang menempuh Studi Strata 1 (S1) Program Studi Ilmu Pemerintahan di Universitas Muhammadiyah Ponorogo. Peneliti menempuh pendidikan MTS di AlIslam Ponorog dan lulus pada tahun 2012. Setelah itu peneliti menempuh pendidikan MA di Al-Islam dan lulus pada tahun 2015. 